\title{
Response by Endodontists to the SARS-CoV-2 (COVID-19) Pandemic: An International Survey
}

\begin{abstract}
Johnah C. Galicia ${ }^{1}$, Rahma Mungia ${ }^{2}$, Melanie V. Taverna ${ }^{2}$, Marissa J. Mendoza ${ }^{3}$, Carlos Estrela ${ }^{4}$, Alexis Gaudin ${ }^{5}$, Chengfei Zhang ${ }^{6}$, B. Aaron Vaughn ${ }^{7}$ and Asma A. Khan ${ }^{8 *}$

${ }^{1}$ Department of Endodontics, Arthur A. Dugoni School of Dentistry, University of the Pacific, San Francisco, CA, United States, ${ }^{2}$ Department of Periodontics, School of Dentistry, University of Texas Health Science Center, San Antonio, TX, United States, ${ }^{3}$ Institute for Integration of Medicine and Science, University of Texas Health Science Center, San Antonio, TX, United States, ${ }^{4}$ Department of Stomatologic Sciences, School of Dentistry, Federal University of Goiás, Goiânia, Brazil, ${ }^{5}$ Department of Endodontics (Rmes U1229, UIC 11), Faculty of Dental Surgery, University of Nantes (CHU de Nantes), Nantes, France, ${ }^{6}$ Restorative Dental Sciences (Endodontics), Faculty of Dentistry, University of Hong Kong, Sai Ying Pun, Hong Kong, ${ }^{7}$ Endodontic Private Practice, San Antonio, TX, United States, ${ }^{8}$ Department of Endodontics, School of Dentistry, University of Texas Health Science Center, San Antonio, TX, United States
\end{abstract}

As SARS-CoV-2 continues to wreak havoc, health care workers are on the front lines to protect our communities. Dentists, particularly endodontists who manage dental emergencies, are engaged in high risk procedures that necessitate the modification of their treatment strategies in order to protect themselves, their staff and their patients from exposure to SARS-CoV-2. This study gathered international data from 448 endodontists to describe their awareness, their clinical care modifications, their strategies for re-opening and their reflection on the effects of the pandemic on their lives. Most endodontic practitioners $(78 \%, n=350)$ provided but limited their treatments to emergency care during the government-mandated shutdowns. They agreed with their local government's actions more than that of the national government, screened their patients for symptoms prior to treatment and changed their clinical care protocol to mitigate the spread of the virus. The pandemic has impacted their income, their ability to retain staff, and their financial and personal outlook in life.

Keywords: COVID - 19, endodontics, survey, clinical practice and treatment, SARS-CoV-2

\section{INTRODUCTION}

In March 2020, < 4 months after the first cluster of cases was reported in China (1), the World Health Organization (WHO) declared the Coronavirus Disease 2019 (COVID-19) a pandemic. As a result, stay at home orders and strict border controls were implemented across the world. This catastrophe exposed the limits of the global healthcare system, with its impact rippling through every aspect of human life (2). As countries continued to battle mounting deaths in the first or second wave of COVID-19 (3), adapting to the new normal, centered around mitigating the spread of the virus, continues to challenge every affected country and government.

The WHO named the etiological agent of COVID-19 as severe acute respiratory syndrome coronavirus 2 (SARS-CoV-2), which belongs to the same family of viruses as SARS-CoV and the Middle East respiratory syndrome coronavirus (MERS-CoV) (4). However, unlike the preceding coronavirus-linked diseases, COVID-19 resulted in considerably higher morbidities and mortality $(1,3)$. SARS-CoV-2 is transmitted mainly through infected fluid droplets expelled by the respiratory 
system of infected individuals while talking, sneezing and coughing (5). Although research on the transmission routes of the virus is still evolving, lowering viral transmission by blocking infected fluid droplets from being discharged in the air and then coming in contact with the mucous membrane or being inhaled by another person (person to person transmission) is the intention of wearing face coverings and physical distancing measures. A mathematical modeling predicted that a consistent use of efficacious masks (i.e., surgical masks) in public by an estimated $80 \%$ of the U.S. population would eliminate the pandemic in the country (6). Furthermore, the use of low efficacy masks (i.e., cloth masks) could also result to a significant reduction of COVID-19 burden (7). The effectiveness of physical distancing, face masks and eye protection in preventing the spread of COVID-19 has provided a strong support of the person-to-person transmission of the disease (8).

Health care workers $(\mathrm{HCW})$ are particularly vulnerable to contracting the virus from exposure to infected body fluids $(9,10)$. SARS-CoV-2 infects the upper respiratory tract with the nasal cavities harboring the highest viral loads (11). Consequently, HCWs who work primarily with the head and neck area are at an increased risk of being infected by SARSCoV-2 (12). In dental practice, saliva has been shown to consistently harbor the virus (13). Aerosol-producing dental treatments are therefore considered high-risk procedures and dental practitioners - dentists, dental hygienists, and dental assistants- belong in the highest stratum of the COVID-19 risk for exposure $(14,15)$. Another compounding factor that increases the person to person penetrability of the SARS-CoV-2 arises from its spread through asymptomatic carriers who serve as nidus for rapid disease transmission $(16,17)$. This makes it particularly hard for HCWs to screen patients for COVID-19 prior to rendering treatment.

Dental practitioners are on the front lines of this struggle to protect our communities. One of the chief concerns among dental practitioners amid the COVID-19 crisis is preventing the transmission of the virus in the workplace $(18,19)$. Specific challenges related to preventing transmission include acquiring adequate personal protective equipment (PPE) and supplies (20), appropriate screening protocols for patients (21), and staff training to ensure compliance with new national and local regulations (22). While various actions have been taken by national and local governments to control the spread of the virus (23), dental practitioners cannot assure awareness or assume a compliant attitude of the local population (24). Updates to dental infection control procedures and best practices have been issued to minimize nosocomial spread in the dental setting (25). However, the inconsistency of recommendations by governments worldwide and misinformation on the internet (26) add to confusion among patients and healthcare workers (27).

Besides keeping the staff and patients safe from the virus, dental clinics must also weather the business and economic impact of the pandemic. An economic analysis on dental practices reported a $29 \%$ negative profit over the course of 1 year due to the effect of the COVID-19 shutdowns (28). To remain clinically operational, clinicians may have to gain access to lending and disaster aid, mitigate staffing challenges, as well as manage stress and mental health (29). The pandemic has brought traumatic stress, moral dilemmas, and socioeconomic transformation as the world grapples with increasing mortality, job loss, and uncertainties while adapting to new realities (30-32).

The purpose of this study was to gather international data from endodontic practitioners to describe their awareness and agreement with national and local "orders" regarding practice behaviors during the pandemic, their clinical care modifications during and after the mandated practice closures, their re-opening strategies for mitigating the spread of the virus, and their reflection on the effects of the pandemic on their lives.

\section{MATERIALS AND METHODS}

This study engaged dental practitioners (primarily endodontists, with general dentists and dental hygienists) in the Unites States (U.S.), as members of the American Association of Endodontics (AAE), University of Pacific San Francisco, University of Texas Health Science Center at San Antonio (UT Health San Antonio) and the South Texas Oral Health Network (STOHN), a Texas Dental Practice-Based Research Network (PBRN). Internationally, it engaged members of the Brazilian Endodontic Association and practitioners from the University of Nantes France, and the University of Hong Kong. The study was approved by The UT Health San Antonio Institutional Review Board. A random selection of 6,247 dental practitioners were invited to participate in this cross-sectional survey study.

Respondents were licensed in the U.S. and Internationally, members of research networks and/or dental associations, faculty at academic dental institutions and those who maintained an active e-mail address where they could be contacted. The survey was delivered online using the web-based survey platform Qualtrics $\mathrm{XM}^{\mathrm{TM}}$, and consisted of 33 items, and is publicly available at https://uthscsa.co1.qualtrics.com/jfe/form/ SV_bKQvQZNt6xMw2Jn. Topic areas included characteristics, practice characteristics, timeframe of the SARS-CoV-2 virus, response to the virus by local, regional, and national authorities, and practice and personal changes in response to the virus.

The study team included three endodontists, one general dentist with public health and PBRN expertise, one dental hygienist with PBRN expertise, and one STOHN PBRN research coordinator. An initial draft of the survey instrument was reviewed by the entire study team for critical feedback regarding content, clarity, and presentation. The survey was piloted with the study team in the survey platform for data collection and management. This iterative development and pilot process maximizes dental practitioner input to increase the relevance of the survey and its findings to dental practitioners.

The study was implemented by the STOHN research coordinator, who utilized the Network's established communication methods to inform and recruit prospective dental practitioners. Study recruitment took place from June 16, 2020, through July 22, 2020. Dental practitioners received an e-mail invitation explaining the study and inviting them to participate using a web link to the questionnaire. 
Taking the survey was voluntary and anonymous. Although dental practitioners could complete the survey in multiple visits, it was recommended to complete in a single sitting. Practitioners received 2 weekly e-mail reminders from the STOHN research coordinator or the representative of the participating organizations. Practitioners who did not responded after 4 weeks (and 3 reminders) received up to 2 additional final reminders. We considered practitioners who had not completed the survey within 10-week time frame non-respondents. Respondents were not offered remuneration for time spent completing the survey, which may have had a negative effect on the overall response rate.

Variables assessed included: practitioner and practice characteristics (practice type, location, patient characteristics), timeframe of awareness of COVID-19 (first awareness, date ranges of government stay-at home orders, practice and personal responses to government order), practice changes made in response to COVID-19 (patient screening, safety, concerns about treating patients, stratification of urgent treatment categories, current and future financial impact of COVID-19 on practices). Data were analyzed using IBM SPSS v26, statistical software computing frequency distributions and descriptive statistics for variables of interest. Data were cleaned by removing incomplete responses from the dataset and analysis. This report will focus only on the response of endodontists to the COVID-19 pandemic.

\section{RESULTS AND DISCUSSION}

\section{Respondent Characteristics}

A total of 448 endodontists completed the anonymous on-line survey. Table 1 presents a detailed descriptive information about participating endodontists and their respective place of practice. The majority were from the US $(72.1 \%, n=323)$ followed by Brazil (20.8\%, $n=93)$, Canada $(2.0 \%, n=9)$, France $(1.8 \%, n$ $=8)$, Hong Kong SAR $(1.6 \%, n=7)$ and then by Australia, Cote D'Ivoire, Mexico, New Zealand and Saudi Arabia with $<1 \%$ each. Participating practitioners were predominantly male $(65.6 \%, n=$ 294 ) and practiced in a solo practices $(37.1 \%, n=166)$. Fourhundred and nineteen respondents described their practice as residing in a non-rural setting (93.5\%).

Greater than one-half of the respondents $(58 \%, n=260)$ reported 16 or more years in practice, followed by 6-10 years $(17.0 \% n=76), 11$ to 15 years $(14.7 \%, n=66)$, and $<5$ years $(10.3 \%, n=46)$ (Table 1). Most of the respondents $(87.5 \%, n=$ 392) indicated they were part of some type of research network or professional network locally or nationally.

\section{Response by Endodontists to the Pandemic: Awareness and Initial Response} Many of the respondents learned about COVID-19 in December, 2019 (38.4\%, $n=172$ ), followed closely by those who learned about it in January, $2020(37.3 \%, n=167)$ (Table 2). Stayat-home orders (SAHO) were implemented primarily between March 11-20, 2020 for $61.4 \%(n=275)$ of the respondents. Surprisingly, 46 respondents $(10.3 \%)$ indicated that their local
TABLE 1 | Respondent characteristics $N=448$

\begin{tabular}{|c|c|c|}
\hline Gender & $\%$ & Number \\
\hline Male & 65.6 & 294 \\
\hline Female & 34.4 & 154 \\
\hline \multicolumn{3}{|l|}{ Length of practice } \\
\hline 16 years and more & 58.0 & 260 \\
\hline $6-10$ years & 14.7 & 66 \\
\hline $11-15$ years & 17.0 & 76 \\
\hline$<5$ years & 10.3 & 46 \\
\hline \multicolumn{3}{|l|}{ Nature of practice } \\
\hline Solo & 37.1 & 166 \\
\hline Group endodontics & 34.4 & 154 \\
\hline Multi-specialty & 7.8 & 35 \\
\hline Full time educator & 7.4 & 33 \\
\hline Faculty practice & 6.9 & 31 \\
\hline Group with general practice & 1.3 & 6 \\
\hline Community & 1.1 & 5 \\
\hline Other & 4.0 & 18 \\
\hline \multicolumn{3}{|l|}{ Practice classification } \\
\hline Non-rural & 93.5 & 419 \\
\hline Rural & 6.5 & 29 \\
\hline \multicolumn{3}{|l|}{ Countries } \\
\hline USA & 72.1 & 323 \\
\hline Brazil & 20.8 & 93 \\
\hline Canada & 2.0 & 9 \\
\hline France & 1.8 & 8 \\
\hline Hong Kong (S.A.R.) & 1.6 & 7 \\
\hline Australia & 0.9 & 4 \\
\hline Cote D'Ivoire & 0.2 & 1 \\
\hline Mexico & 0.2 & 1 \\
\hline New Zealand & 0.2 & 1 \\
\hline Saudi Arabia & 0.2 & 1 \\
\hline
\end{tabular}

authority imposed a SAHO as early as between March 1$-10,2020$ Among the countries who responded to the survey, Hong Kong SAR $(1.6 \%, n=7)$ was the earliest to issue a SAHO in early January (33). In the U.S., the Bay Area in California (13.9\%, $n=45$ ) was the first to implement a SAHO in March 17, 2020 (34), which was earlier than Australia (March 22, 2020) (35) and the rest of the other countries in the survey. The early shutdown in Hong Kong, together with their stringent transmission and protective measures, has been considered instrumental to the successful "flattening of the curve" in a large urban area that had similar dangerous outbreaks in the past (36).

The response of endodontic practitioners to COVID-19 is dependent on the decisions and actions of their national and local governing bodies that formulate and enforce orders to protect and prepare their constituents. From the survey, we found that the respondents trusted the response of their local government (state or prefect) more than they trusted their national government. Compared to the $71.8 \%(n=322)$ that agreed in varying levels to the timeliness and appropriateness of their local government's COVID-19 response, only $45.4 \%$ ( $n$ 
TABLE 2 | Awareness and Response to Covid-19 by endodontic practitioners, $N=448$.

\begin{tabular}{|c|c|c|}
\hline Initial awareness & $\%$ & Number \\
\hline Dec. 2019 & 38.4 & 172 \\
\hline Jan. 2020 & 37.3 & 167 \\
\hline Feb. 2020 & 19.2 & 86 \\
\hline Mar. 2020 & 5.1 & 23 \\
\hline \multicolumn{3}{|c|}{ Response to initial stay-at-home order } \\
\hline Emergency services only & 78.1 & 350 \\
\hline Total shutdown & 19.2 & 86 \\
\hline Normal operation & 2.7 & 12 \\
\hline \multicolumn{3}{|l|}{ Patient screening protocol* } \\
\hline Fever $\left(>100^{\circ} \mathrm{F}\right)$ & 97.8 & 438 \\
\hline Cough & 96.0 & 430 \\
\hline Sore Throat & 95.1 & 426 \\
\hline Shortness of breath & 90.4 & 405 \\
\hline Flu-like symptoms & 82.4 & 369 \\
\hline Muscle pain & 81.5 & 365 \\
\hline Vomiting, diarrhea & 59.8 & 268 \\
\hline Runny nose & 50.4 & 226 \\
\hline Red or painful, scratchy eyes & 50.0 & 224 \\
\hline Pulse oximeter (<90\%) & 34.6 & 155 \\
\hline Travel history & 29.9 & 134 \\
\hline Other & 11.6 & 52 \\
\hline \multicolumn{3}{|l|}{ Changes in patient care* } \\
\hline Virtual health (e.g., triaging) & 92.0 & 412 \\
\hline Ramped up PPEs & 77.0 & 345 \\
\hline Changes clinic lay-out & 69.9 & 312 \\
\hline No aerosol producing step & 41.1 & 184 \\
\hline Negative pressure equipment & 16.1 & 72 \\
\hline Stringent aseptic measures & 77.2 & 68 \\
\hline Others & 7.6 & 34 \\
\hline
\end{tabular}

* Respondents can choose more than one answer.
$=203$ ) agreed with that of their national government (Table 3). These results echo the news and criticisms of the federal government's response in the U.S $(37,38)$ and Brazil $(39)$, two of the worst-hit countries in the world (40).

Dentists, particularly endodontists, are frontline workers during the pandemic. The dental emergency can be a devastating experience that can result in systemic infection. Emergency dental care is therefore necessary, which creates a dilemma in balancing patient care with personnel safety (41). As a result of the SAHO and to address the emergency needs of their patients, $78.1 \%(n=350)$ of the endodontic practitioners limited the provision of endodontic treatment to emergency cases only. Eighty-six (19.2\%) of respondents had closed their practice while $2.7 \%(n=12)$ continued with normal operations (Table 2). Extraoral swelling, severe pain and traumatic fracture of teeth were considered as the most urgent emergency cases by the respondents.

\section{Practice Modifications by Endodontic Practitioners}

Dental procedures are considered high-risk practices for contracting COVID-19 $(9,11)$. The Centers for Disease Control (CDC) in the U.S. formulates continuously evolving guidelines for infection prevention and control in dental settings specific for COVID-19 (42). Among the many changes that were implemented to their practice (respondents could choose more than one answer) (Figure 1), 92.0\% $(n=412)$ instituted virtual health, including triaging and $77 \%(n=345)$ ramped up PPEs compared to pre-COVID-19 period, which included counter-top plexiglass barriers, use of N95 mask, face shield, body suits, and others. This was followed by $69.6 \%(n=312)$ made changes to layout of traffic flow in their clinic (e.g., separate entrance and exit, 6 -ft markers), $41.1 \%$ ( $n=184$ ) chose to stop performing aerosol-producing procedures using ultrasonic tips and watercooled high-speed handpieces, $16.1 \%(n=72)$ installed negative

TABLE 3 | Respondents' opinion on government and workplace response to Covid-19 (\%).

\begin{tabular}{|c|c|c|c|c|c|c|c|c|}
\hline & $\begin{array}{l}\text { Strongly } \\
\text { agree }\end{array}$ & Agree & $\begin{array}{l}\text { Somewhat } \\
\text { agree }\end{array}$ & $\begin{array}{l}\text { Neither } \\
\text { agree nor } \\
\text { disagree }\end{array}$ & $\begin{array}{l}\text { Somewhat } \\
\text { disagree }\end{array}$ & Disagree & $\begin{array}{l}\text { Strongly } \\
\text { disagree }\end{array}$ & N/A \\
\hline $\begin{array}{l}\text { The action of my state government } \\
\text { was timely and appropriate }\end{array}$ & 14.7 & 30.1 & 27.0 & 5.1 & 8.5 & 7.1 & 6.7 & 0.7 \\
\hline $\begin{array}{l}\text { I trust the actions and decisions of my } \\
\text { government's COVID-19 } \\
\text { policy-making body. }\end{array}$ & 7.1 & 20.5 & 24.8 & 7.1 & 12.9 & 13.2 & 13.6 & 0.7 \\
\hline $\begin{array}{l}\text { My professional group has been } \\
\text { supportive during the pandemic. }\end{array}$ & 34.2 & 37.5 & 14.1 & 5.1 & 4.9 & 2.2 & 1.8 & 0.2 \\
\hline
\end{tabular}




\section{CHANGES IN PATIENT CARE}

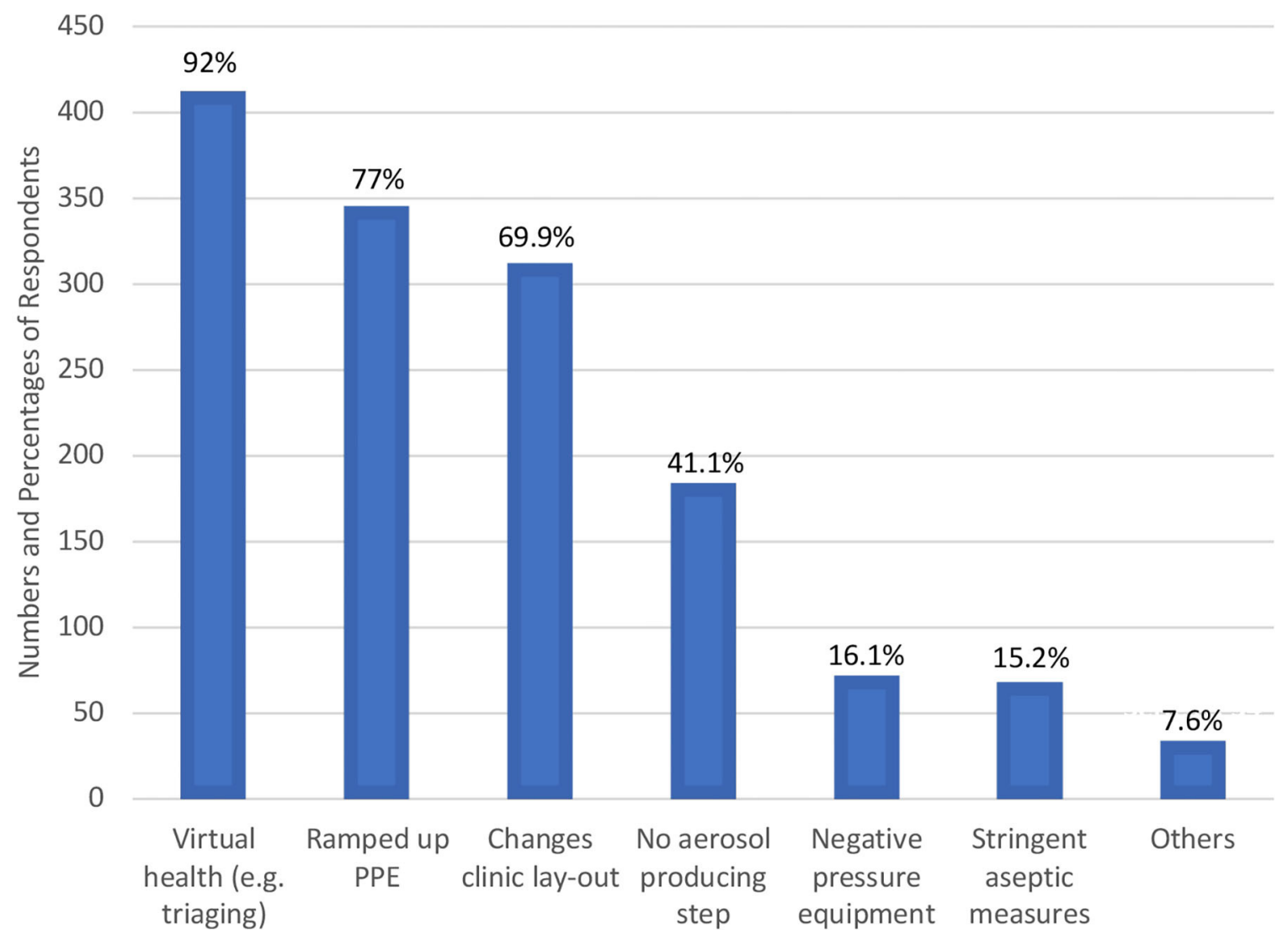

FIGURE 1 | Changes implemented in Clinical Practice in response to COVID-19. Respondents were permitted to select multiple options on changes made to prevent the transmission of SARs CoV-2 in their dental practices. Virtual Health Triaging was the most common change made by the survey respondents.

pressure equipment, and $15.2 \%(n=68)$ chose stringent aseptic measures like shortened treatment time, full wipe down after each patient, reduced patient capacity, pre-treatment mouth rinse, use of dental dam isolation in all procedures and other methods such as installation of aerosol vacuuming system, improved air filtering and use of ultraviolet light sanitizers. Possible aerosol transmission of COVID-19 has been a concern and a subject of debate (43).

With regard to patient management, pre-treatment screening has been implemented to include checking for temperature, coughing, shortness of breath, sore throat, flu-like symptoms, pulse oximeter reading, travel history and others (Table 2). Screening for patients contributed to the feeling of safety in $73 \%$ ( $n=327$ ) of the respondents; however, the remaining $27 \%$ were either unsure or did not feel safe even with patient pretreatment screenings. These results were in agreement with the feeling of overall safety in working with patients during the pandemic. In spite of the concerns with aerosols and dental procedure, there have been no reported clusters of respiratorytransmitted diseases, including COVID-19 and other severe, infectious respiratory diseases in dental settings (44). Several clinical recommendations on the practice of endodontics amid the pandemic can be reviewed elsewhere $(45,46)$.

\section{Financial Impact of Covid-19 on Endodontic Practice}

The SAHO, disease transmission concerns and the modifications to patient care severely disrupted the patient continuity of care in over $80 \%$ of the respondents. Even with the resumption of elective dental care, $49.3(n=221)$ of the respondents indicated that their patients expressed apprehensions in visiting a dentist. The significant disruption of care and patients' dental treatment concerns caused a negative impact on the income of over $90 \%$ of the respondents (Figure 2). 3.6\% $(n=16)$ reported total loss of business.

Due to the financial impact of the pandemic on small and medium-sized enterprises, countries like Brazil and the U.S. provided financial support to their citizens. In the U.S., coronavirus relief options were offered to small business through the U.S. Small Businesses Administration (SBA) (47). These relief options included Payment Protection Program (PPP), Economic 


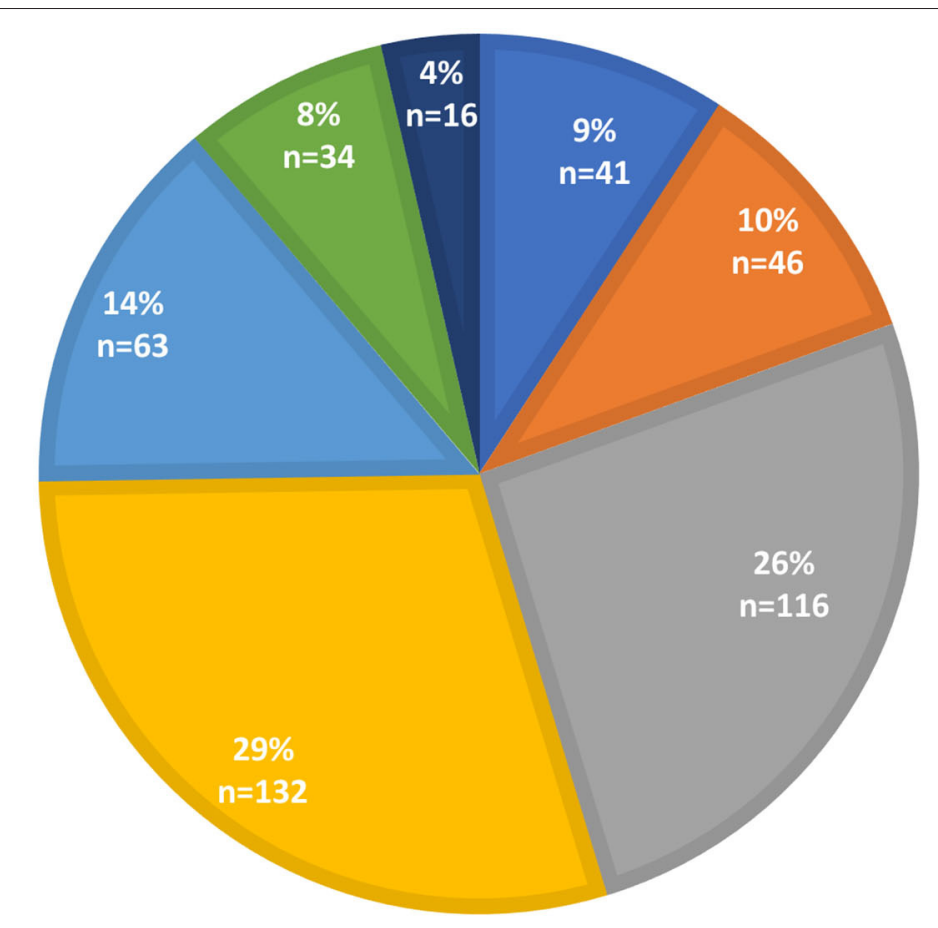

No negative impact

Less than $10 \%$

Over $10 \%$ but less than $25 \%$

Over $25 \%$ but less than $50 \%$

Over $50 \%$ but less than $75 \%$

More than $75 \%$

Total loss of business

FIGURE 2 | Financial impact of COVID-19. Survey results indicate that the pandemic had a negative impact on over $90 \%$ of the respondents with $3.6 \%$ reporting a total loss of business.

Injury Disaster Loans (EIDL), SBA Debt Relief and others. In Brazil, coronavirus emergency benefits were distributed to households (48). The benefits consisted of emergency salary paid to those who lost their income during the pandemic, as well as monetary supplement to those who suffered pay cuts due to COVID-19.

Among the respondents of this survey, 37.1\% $(n=166)$ did not receive any form of government assistance for their practice. $5.2 \%(n=24)$ received $<10,000$ U.S. dollars, $4.3 \%$ $(n=20)$ received over 10,000 but $<20,000$ and $13.8 \%(n$ $=62$ ) received over 20 but $<50,000$ dollars. The rest of the respondents received over 50,000 and up to two hundred fifty thousand dollars. Financial stability or receipt of government assistance like PPP of $40.4 \%(n=181)$ of endodontic practices allowed them to keep their staff working full-time (Figure 3). However, $25.4 \%(n=114), 17.4 \%(n=78)$ and $5.8 \%(n=26)$ furloughed, reduced or laid-off their staff, respectively. The rest of the endodontic practices kept but reduced the working hours of their staff, redeployed their staff to other practices, encountered issues of staff refusing to return to work and others. Respondents from France, the U.S. and New Zealand indicated that their staff received wage subsidy from the government.

In the U.S., the Department of Labor data indicate that as of October 2020, 28 million U.S. workers are either on unemployment benefits or have applied recently and are waiting to get approved (49). This rise in the number of unemployed workers due to COVID-19 is substantially greater than the increase due to the Great Recession (50).

\section{What Does the Future Hold for Endodontic Practitioners?}

As of October 1, 2020, COVID-19 has infected 34,124,948 people with $1,016,723$ fatalities (40). The U.S. ranks on top with the greatest number of infections $(7,268,298)$ and fatalities $(207,605)$. Brazil ranks third in infections $(4,810,935)$ and second in fatalities $(143,952)$. From the CDC reports, there is a trend toward higher hospitalization rates among people who are Hispanic/Latino, non-Hispanic Black and non-Hispanic American Indian/Alaska natives (51). Hong Kong, Canada, France, Australia and New Zealand have been relatively successful in slowing down both the infection and fatality rates (40). However, the recent re-openings and easing-up of restrictions in public services have led to spikes in infection. Furthermore, the public is being warned of a worse COVID-19 scenario as fall and winter seasons approach $(52,53)$.

The arrival of an effective vaccine was ranked by endodontists as the most important factor in combating COVID-19 (55.6\%, $n$ $=249)$ followed using appropriate PPEs $(14.1 \%, n=63)$, herd immunity $(11.6 \%, n=52)$, viral or antibody testing $(4.7 \%, n$ $=21$ ) and others. Early in the pandemic, the shortage of PPEs became the worst concern for endodontists who were treating patients $(57.8 \%, n=259)$; however, as supplies stabilized and more knowledge about COVID-19 has emerged in the scientific community, this concern has been addressed effectively.

According to the WHO, there are currently over 169 COVID19 vaccine candidates under development, with 26 of these in the human trial phase (54). The WHO is supporting the building of manufacturing capabilities and buying supply ahead 


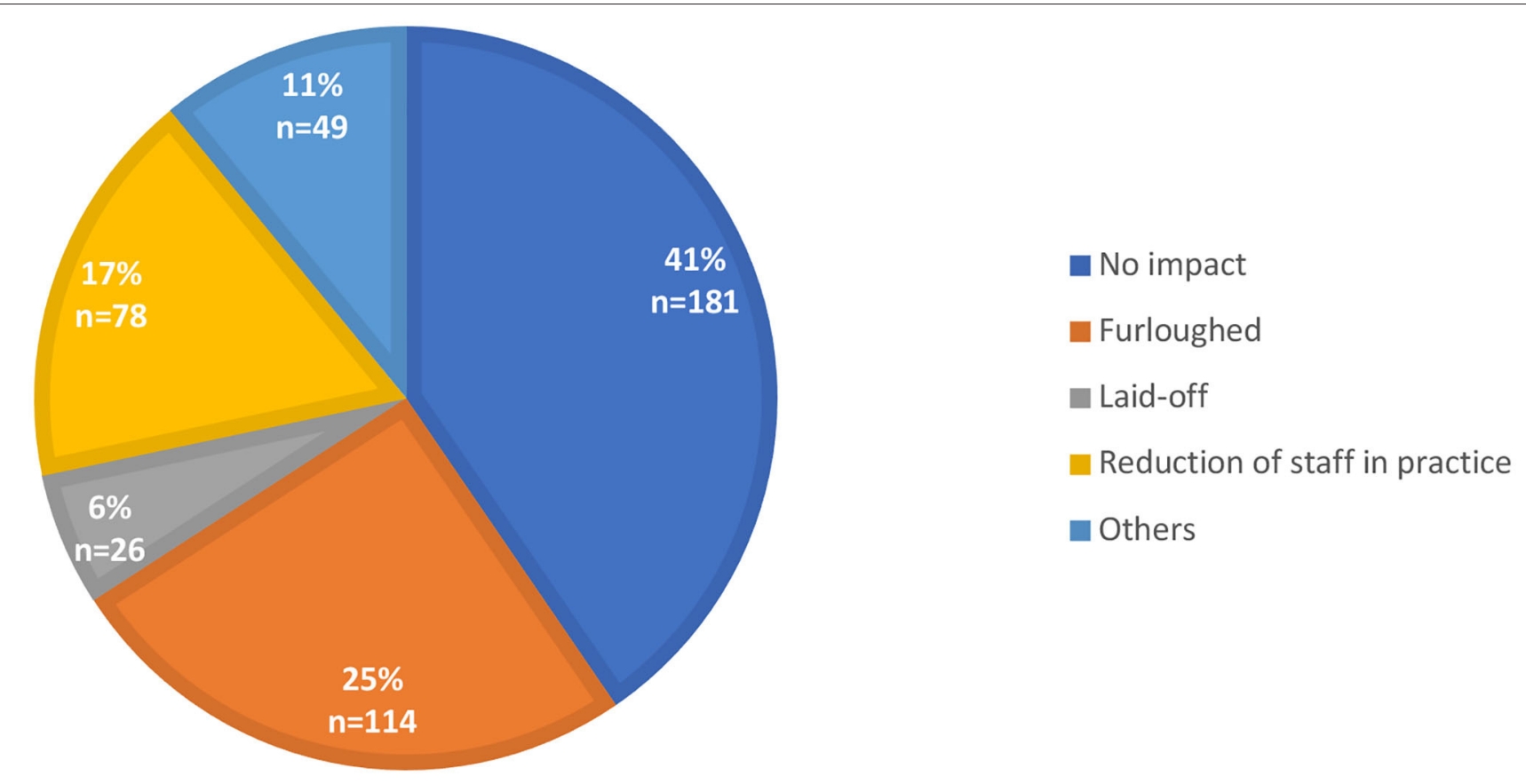

FIGURE 3 | Impact of COVID-19 on dental staff. The pandemic had a significant impact on the dental staff in over $50 \%$ of endodontic practices surveyed. In a small percentage of the practices the staff were laid-off while others had to reduce the working hours, furlough staff or redeploy them to other practices.

of time so that 2 billion doses of the COVID-19 vaccine (Covax) can be fairly distributed by the end of 2021. As of now, the efficacy of COVID-19 vaccines and the achievement of herd immunity are evolving knowledge with plenty of moving parts. Antiviral drugs that may decrease viral loads and consequently reduce transmission, or therapeutics that avert complications and prevent fatalities, may become more significant for COVID-19 control in the coming months. This will be the scenario until vaccines become available, which will allow us to achieve herd immunity in the safest possible way (52).

Until this pandemic is over, the survey respondents echoed their worries about the future of their financial situation $(63 \%$, $n=282)$ and of their personal life $(55.8 \%, n=250)$ (Table 4$)$. This is echoed in other surveys on the impact of COVID (18). However, there is still optimism in the future of endodontics as $42.9 \%(n=192)$ believe that the specialty will be fine. $46.9 \%$ ( $n=$ $210)$ worry and $10.3 \%(n=46)$ neither agree nor disagree that the pandemic will be a concern for the future of the endodontic field.

\section{COVID-19 and the Global Research Community}

While this pandemic has devastated communities across the globe, it also served to draw attention to the significant advances in biotechnology that have occurred over the past few decades. The infection was first reported in the Fall of 2019 and the Sars-CoV-2 genome was posted on January 10, 2022. Vaccine development which normally requires years was completed in 2 months. At the point of the publication of this article, there are at several vaccines in Phase II clinical trial (54). What is even more interesting is that these include mRNA vaccines, which are immunostimulatory but not infectious.

Another advantage conferred by technology is the ability to share knowledge and communicate with colleagues. Biomedical journals granted non-subscribers access to publications on SARSCoV-2 free of charge thus helping disseminate knowledge in a timely manner. Webinars proved to be a powerful tool of communication for professional organizations such as the $\mathrm{ADA}$ and the AAE. Electronic surveys such as the one in this publication, gather information on practice behaviors and on the effects of the pandemic on the lives of dentists. These will identify both strengths and deficiencies in our response and leave us better prepared for the next epidemic or pandemic.

Several decades ago, the HIV pandemic led to changes in infection control practices in dentistry. These included the use of gloves, sterilization of instruments and others. While all of these were based on the understanding that HIV spreads through bodily fluids, they provide protection from other infections such as Hepatitis C. In contrast, SarsCoV-2 is airborne and will lead to changes directed toward protection from aerosols. For example, there have been several innovative reports on methods to redirect the aerosols away from the operating dentists and assistants (55). It is likely that there will be further development of technologies to remove SarsCoV-2 from dental operatories which will provide protection from other airborne viral infections as well.

The impact of SARS CoV-2 on oral health is yet to be fully elucidated. The virus has been consistently detected in saliva (13). Its cellular receptor angiotensin converting enzyme 2 (ACE2) and the associated cellular serine protease TPMRSS2 are both 
TABLE 4 | Impact of Covid-19 to endodontic practitioners' outlook (\%).

\begin{tabular}{|c|c|c|c|c|c|c|c|c|}
\hline & $\begin{array}{c}\text { Strongly } \\
\text { agree }\end{array}$ & Agree & $\begin{array}{c}\text { Somewhat } \\
\text { Agree }\end{array}$ & $\begin{array}{l}\text { Neither } \\
\text { Agree nor } \\
\text { Disagree }\end{array}$ & $\begin{array}{c}\text { Somewhat } \\
\text { Disagree }\end{array}$ & Disagree & $\begin{array}{l}\text { Strongly } \\
\text { Disagree }\end{array}$ & N/A \\
\hline $\begin{array}{l}\text { I feel safe working with } \\
\text { patients during the } \\
\text { COVID-19 pandemic. }\end{array}$ & 23.9 & 35.0 & 18.5 & 5.1 & 6.0 & 7.6 & 2.9 & 0.9 \\
\hline $\begin{array}{l}\text { I am worried about my } \\
\text { future financial situation } \\
\text { because of COVID-19. }\end{array}$ & 14.5 & 21.0 & 27.5 & 11.4 & 7.4 & 12.9 & 5.4 & \\
\hline $\begin{array}{l}\text { I am worried about the } \\
\text { future of my profession } \\
\text { because of COVID-19. }\end{array}$ & 11.2 & 15.4 & 20.3 & 10.3 & 12.7 & 19.9 & 10.3 & \\
\hline $\begin{array}{l}\text { I am worried about my } \\
\text { personal life in the future } \\
\text { because of COVID-19. }\end{array}$ & 12.3 & 21.4 & 22.1 & 12.1 & 7.6 & 16.3 & 8.3 & \\
\hline
\end{tabular}

expressed in the dental pulp making it likely that the pulp is vulnerable to the virus (56). What is not known is whether the presence of the virus and the cytokine storm that it instigates impacts pulpal disease. Dental pulp cells harbor viral microRNA which potentially affect the pulpal response to viral infection (57). The role of Sars-COV-2 in modulating host-bacterial interaction in the pulp is of particular importance given the high incidence of pulpitis and the rate of SARS-COV-2 positivity in multiple communities across the world.

The current and lingering effects of this pandemic to every aspect of our lives have been a source of grief and frustration; however, it also underscored the resilience of the human spirit.

\section{REFERENCES}

1. Zhu N, Zhang D, Wang W, Li X, Yang B, Song J, et al. A novel coronavirus from patients with pneumonia in China, (2019). N Engl J Med. (2020) 382:727-33. doi: 10.1056/NEJMoa2001017

2. Nicola M, Alsafi Z, Sohrabi C, Kerwan A, Al-Jabir A, Iosifidis C, et al. The socio-economic implications of the coronavirus pandemic (COVID-19): a review. Int J Surg. (2020) 78:185-93. doi: 10.1016/j.ijsu.2020.04.018

3. Dong E, Du H, Gardner L. An interactive web-based dashboard to track COVID-19 in real time. Lancet Infect Dis. (2020) 20:533-4. doi: 10.1016/S1473-3099(20)30120-1

4. International Committee on Taxonomy of Viruses Executive C. The new scope of virus taxonomy: partitioning the virosphere into 15 hierarchical ranks. Nat Microbiol. (2020) 5:668-74. doi: 10.1038/s41564-020-0709-x

5. Anfinrud P, Stadnytskyi V, Bax CE, Bax A. Visualizing speech-generated oral fluid droplets with laser light scattering. N Engl J Med. (2020) 382:20613. doi: 10.1056/NEJMc2007800

6. Ngonghala CN, Iboi E, Eikenberry S, Scotch M, MacIntyre CR, Bonds $\mathrm{MH}$, et al. Mathematical assessment of the impact of non-pharmaceutical interventions on curtailing the 2019 novel coronavirus. Math Biosci. (2020) 325:108364. doi: 10.1016/j.mbs.2020.108364

7. Zangmeister CD, Radney JG, Vicenzi EP, Weaver JL. Filtration efficiencies of nanoscale aerosol by cloth mask materials used to slow the spread of SARS-CoV-2. ACS Nano. (2020) 14:9188-200. doi: 10.1021/acsnano.0c05025

8. Chu DK, Akl EA, Duda S, Solo K, Yaacoub S, Schunemann HJ, et al. Physical distancing, face masks, and eye protection to prevent person-toperson transmission of SARS-CoV-2 and COVID-19: a systematic review and meta-analysis. Lancet. (2020) 395:1973-87. doi: 10.1016/j.jvs.2020.07.040

\section{DATA AVAILABILITY STATEMENT}

The original contributions presented in the study are included in the article/supplementary materials, further inquiries can be directed to the corresponding author/s.

\section{AUTHOR CONTRIBUTIONS}

JG and AK conceived the study. JG, AK, RM, MT, and MM designed the study and analyzed the data. RM, MT, MM, CE, $\mathrm{AG}$, and $\mathrm{CZ}$ distributed the study. JG, AK, RM, MT, MM, and BV wrote the manuscript. All authors reviewed and approved the manuscript.

9. Sim MR. The COVID-19 pandemic: major risks to healthcare and other workers on the front line. Occup Environ Med. (2020) 77:2812. doi: 10.1136/oemed-2020-106567

10. Verbeek JH, Rajamaki B, Ijaz S, Sauni R, Toomey E, Blackwood B, et al. Personal protective equipment for preventing highly infectious diseases due to exposure to contaminated body fluids in healthcare staff. Cochrane Database Syst Rev. (2020) 5:CD011621. doi: 10.1002/14651858.CD01162 1.pub5

11. Zou L, Ruan F, Huang M, Liang L, Huang H, Hong Z, et al. SARS-CoV-2 viral load in upper respiratory specimens of infected patients. N Engl J Med. (2020) 382:1177-9. doi: 10.1056/NEJMc2001737

12. Thamboo A, Lea J, Sommer DD, Sowerby L, Abdalkhani A, Diamond $\mathrm{C}$, et al. Clinical evidence based review and recommendations of aerosol generating medical procedures in otolaryngology - head and neck surgery during the COVID-19 pandemic. J Otolaryngol Head Neck Surg. (2020) 49:28. doi: 10.1186/s40463-020-00425-6

13. To KK, Tsang OT, Chik-Yan Yip C, Chan KH, Wu TC, Chan JMC, et al. Consistent detection of 2019 novel coronavirus in saliva. Clin Infect Dis. (2020) 71:841-3. doi: 10.1093/cid/ciaa149

14. Administration OSH. Covid-19 Hazard Recognition. Washington, DC: OSHA (2020).

15. Ali K, Raja M. Coronavirus disease 2019 (COVID-19): challenges and management of aerosol-generating procedures in dentistry. Evid Based Dent. (2020) 21:44-5. doi: 10.1038/s41432-0200088-4

16. de Wit E, van Doremalen N, Falzarano D, Munster VJ. SARS and MERS: recent insights into emerging coronaviruses. Nat Rev Microbiol. (2016) 14:523-34. doi: 10.1038/nrmicro.2016.81 
17. Gandhi M, Yokoe DS, Havlir DV. Asymptomatic transmission, the achilles' heel of current strategies to control covid-19. N Engl J Med. (2020) 382:215860. doi: 10.1056/NEJMe2009758

18. Martinho FC,Griffin IL. A cross-sectional survey on the impact of coronavirus disease 2019 on the clinical practice of endodontists across the United States. J Endod. (2020) 47:28-38. doi: 10.1016/j.joen.2020. 10.002

19. Ahmed MA, Jouhar R, Ahmed N, Adnan S, Aftab M, Zafar MS, et al. Fear and practice modifications among dentists to combat novel coronavirus disease (COVID-19) outbreak. Int J Environ Res Public Health. (2020) 17:2821. doi: 10.3390/ijerph17082821

20. Garcia Godoy LR, Jones AE, Anderson TN, Fisher CL, Seeley KML, Beeson EA, et al. Facial protection for healthcare workers during pandemics: a scoping review. BMJ Glob Health. (2020) 5:e002553. doi: 10.1136/bmjgh-2020002553

21. Gostic K, Gomez AC, Mummah RO, Kucharski AJ, Lloyd-Smith JO. Estimated effectiveness of symptom and risk screening to prevent the spread of COVID19. Elife. (2020) 9:e55570. doi: 10.7554/eLife.55570

22. Gallagher JE, Johnson I, Verbeek JH, Clarkson JE, Innes N. Relevance and paucity of evidence: a dental perspective on personal protective equipment during the COVID-19 pandemic. Br Dent J. (2020) 229:1214. doi: 10.1038/s41415-020-1843-9

23. Lai CC, Wang CY, Wang YH, Hsueh SC, Ko WC, Hsueh PR. Global epidemiology of coronavirus disease 2019 (COVID-19): disease incidence, daily cumulative index, mortality, and their association with country healthcare resources and economic status. Int J Antimicrob Agents. (2020) 55:105946. doi: 10.1016/j.ijantimicag.2020.105946

24. Kouzy R, Abi Jaoude J, Kraitem A, El Alam MB, Karam B, Adib E, et al. Coronavirus goes viral: quantifying the COVID-19 misinformation epidemic on twitter. Cureus. (2020) 12:e7255. doi: 10.7759/cureus. 7255

25. Ather A, Patel B, Ruparel NB, Diogenes A, Hargreaves KM. Coronavirus disease 19 (COVID-19): implications for clinical dental care. J Endod. (2020) 46:584-95. doi: 10.1016/j.joen.2020.03.008

26. Cuan-Baltazar JY, Munoz-Perez MJ, Robledo-Vega C, Perez-Zepeda MF, Soto-Vega E. Misinformation of COVID-19 on the internet: infodemiology study. JMIR Public Health Surveill. (2020) 6:e18444. doi: 10.2196/ 18444

27. Bhagavathula AS, Aldhaleei WA, Rahmani J, Mahabadi MA, Bandari DK. Knowledge and perceptions of COVID-19 among health care workers: cross-sectional study. JMIR Public Health Surveill. (2020) 6:e19160. doi: 10.2196/19160

28. Schwendicke F, Krois J, Gomez J. Impact of SARS-CoV2 (Covid19) on dental practices: economic analysis. J Dent. (2020) 2020:103387. doi: 10.1016/j.jdent.2020.103387

29. Walton M, Murray E, Christian MD. Mental health care for medical staff and affiliated healthcare workers during the COVID-19 pandemic. Eur Heart J Acute Cardiovasc Care. (2020) 9:241-7. doi: 10.1177/204887262092 2795

30. Coulthard P. Dentistry and coronavirus (COVID-19) - moral decisionmaking. Br Dent J. (2020) 228:503-5. doi: 10.1038/s41415-020-1482-1

31. Horesh D, Brown AD. Traumatic stress in the age of COVID-19: a call to close critical gaps and adapt to new realities. Psychol Trauma. (2020) 12:331-5. doi: $10.1037 /$ tra0000592

32. Noda Y. Socioeconomical transformation and mental health impact by the COVID-19's ultimate VUCA era: toward the new normal, the new Japan, and the new world. Asian J Psychiatr. (2020) 54:102262. doi: 10.1016/j.ajp.2020.102262

33. Marlow I. Hong Kong Shutdown a Lesson to the World in Halting Virus. New York, NY: Bloomberg. (2020).

34. SFDPH. San Francisco Department of Public Health Order. San Francisco, CA: San Francisco Department of Public Health (2020).

35. BBC. Coronavirus: Australia to Close Pubs, Cafes and Places of Worship. BBC News (2020). Available online at: https://www.bbc.com/news/worldaustralia-51992357(accessed March 22, 2020).

36. Wong J, Lee AHC, Zhang C. Effect of COVID-19 on dental education and endodontic practice in Hong Kong. Front Dent Med. (2020) 1:569225. doi: 10.3389/fdmed.2020.569225
37. Yong E. How the Pandemic Defeated America. The Atlantic. (2020). Available online at: https://www.theatlantic.com/magazine/archive/2020/09/ coronavirus-american-failure/614191/(accessed August 4 2020).

38. Kamizar B, Holzberg M. NBC News. Americans Trust Governors more than Trump on Coronavirus, New Poll Finds. (2020). Available online at: https:// www.nbcnews.com/politics/2020-election/americans-trust-governorsmore-trump-coronavirus-new-poll-finds-n1233031 (accessed August 1, 2020).

39. Urban M, Saad-Diniz E. Why Brazil's COVID-19 Response is Failing. The Regulatory Review. (2020). Available online at: https://www.theregreview.org/ 2020/06/22/urban-saad-diniz-brazil-covid-19-response-failing/ (accessed August 5, 2020).

40. JHU. Johns Hopkins Coronavirus Resource Center. Baltimore, MD: Johns Hopkins University and Medicine (2020).

41. Patel B, Eskander MA, Ruparel NB. To drill or not to drill: management of endodontic emergencies and in-process patients during the COVID-19 pandemic. J Endod. (2020) 46:1559-69. doi: 10.1016/j.joen.2020.08.008

42. CDC. Centers for Disease Control Guidance for Dental Settings. (2020). Available online at: https://www.cdc.gov/coronavirus/2019-ncov/hcp/dentalsettings.html (accessed July 7, 2020)

43. Ge Z-Y, Yang L-M, Xia J-J, Fu X-H, Zhang Y-Z. Possible aerosol transmission of COVID-19 and special precautions in dentistry. J Zhejiang Univ Sci B. (2020) 21:361-8. doi: 10.1631/jzus.B2010010

44. Epstein JB, Chow K, Mathias R. Dental procedure aerosols and COVID-19. Lancet Infect Dis. (2020). doi: 10.1016/S1473-3099(20)30636-8 [Epub ahead of print]

45. Azim AA, Shabbir J, Khurshid Z, Zafar MS, Ghabbani HM, Dummer PMH. Clinical endodontic management during the COVID-19 pandemic: a literature review and clinical recommendations. Int Endod J. (2020)53:146171. doi: $10.1111 /$ iej.13406

46. Teichert-Filho R, Baldasso CN, Campos MM, Gomes MS. Protective device to reduce aerosol dispersion in dental clinics during the COVID-19 pandemic. Int Endod J. (2020) 53:1588-97. doi: 10.1111/iej.13373

47. SBA US. Coronavirus Relief Options. (2020). Available online at: https://www. sba.gov/funding-programs/loans/coronavirus-relief-options (accessed June 24, 2020).

48. Castro JR. Almost Half of Brazilian Homes Received Coronavirusemergecy Benefits. The Brazilian Report. (2020). Available online at: https://brazilian. report/coronavirus-brazil-live-blog/2020/07/23/almost-half-of-brazilianhomes-received-coronavirus-emergency-benefits/ (accessed July 23, 2020).

49. EPI US. Economic Policy Institute. With Millions of Workers Receiving Unemployment Benefits and No End in Sight for the COVID-19 Pandemic, Congress must Act. Working Economics Blog. Washington, DC: Economic Policy Institute (2020).

50. Kochhar R. Pew Research. Unemployment Rose Higher in Three Months of COVID-19 than it did in Two Years of the Great Recession. The Pew Research. (2020). Available online at: https://www.pewresearch.org/fact-tank/2020/06/ 11/unemployment-rose-higher-in-three-months- of-covid-19-than-it-didin-two-years-of-the-great-recession/ (accessed June 11, 2020).

51. CDC. US CDC. Coronavirus Disease 2019 (Covid-19).Centers for Disease Control US, USA. (2020). Available online at: https://www.cdc.gov/ coronavirus/2019-ncov/covid-data/data-visualization.htm (accessed October 1, 2020).

52. Fontanet A, Cauchemez S. COVID-19 herd immunity: where are we? Nat Rev Immunol. (2020) 20:583-4. doi: 10.1038/s41577-020-00451-5

53. Pinsker J. The Winter Will Be Worse. The Atlantic. (2020). Available online at: https://www.theatlantic.com/family/archive/2020/08/winter-us-coronaviruspandemic-dangerous-indoors/614965/ (accessed august 5, 2020).

54. WHO. The Push for COVID-19 Vaccine. Geneva: World Health Organization (2020). Available online at: https://www.who.int/emergencies/diseases/novelcoronavirus-2019/covid-19-vaccines (accessed December 13, 2020).

55. Shahdad S, Patel T, Hindocha A, Cagney N, Mueller J-D, Seoudi N, et al. The efficacy of an extraoral scavenging device on reduction of splatter contamination during dental aerosol generating procedures: an exploratory study. Br Dent J. (2020) 11:1-10. doi: 10.1038/s41415-020-2112-7

56. Galicia JC, Guzzi PH, Giorgi FM, Khan AA. Predicting the response of the dental pulp to SARS-CoV2 infection: a transcriptome-wide effect crossanalysis. Genes Immun. (2020) 21:360-3. doi: 10.1038/s41435-020-00112-6 
57. Zhong S, Naqvi A, Bair E, Nares S, Khan AA. Viral microRNAs identified in human dental pulp. J Endod. (2017) 43:84-9. doi: 10.1016/j.joen.2016. 10.006

Conflict of Interest: The authors declare that the research was conducted in the absence of any commercial or financial relationships that could be construed as a potential conflict of interest.
Copyright $\odot 2021$ Galicia, Mungia, Taverna, Mendoza, Estrela, Gaudin, Zhang, Vaughn and Khan. This is an open-access article distributed under the terms of the Creative Commons Attribution License (CC BY). The use, distribution or reproduction in other forums is permitted, provided the original author(s) and the copyright owner(s) are credited and that the original publication in this journal is cited, in accordance with accepted academic practice. No use, distribution or reproduction is permitted which does not comply with these terms. 